\title{
Dysfunction of Collaborative Governance in the Handling Policy of Covid-19 at Jambi Province
}

\author{
Muhammad Ichsan Kabullah ${ }^{1}$, Sudarmoko $^{2}$, Hendri Koeswara ${ }^{3}$, Fajri Rahman ${ }^{4}$, Azwar $^{5}$ \\ ${ }^{1}$ Jurusan Administrasi Publik, FISIP Universitas Andalas: muhammadichsankabullah@soc.unand.ac.id \\ ${ }^{2}$ Jurusan Sastra Indonesia, FIB Universitas Andalas \\ ${ }^{3}$ Jurusan Administrasi Publik, FISIP Universitas Andalas \\ ${ }^{4}$ Jurusan Antropologi, FISIP Universitas Andalas \\ ${ }^{5}$ Jurusan Sosiologi, FISIP Universitas Andalas
}

Received: 15/01/2021

Reviewed: $28 / 03 / 2021$

Published: $31 / 07 / 2021$

Copyright@2021 oleh authors (et al) and Jurnal Sosial Humaniora (JSH)

${ }^{*}$ This work is licensed under the Creative Commons Attribution International License (CC BY 4.0). http://creativecommons.org/licenses/by/4.0/ (c) (i) Open Access

\begin{abstract}
Subject Area: Public Policy
Abstract

Current research on public administration has generally concluded that collaborative governance is a critical factor in solving the contemporary crisis. Collaborative governance has been suggested as a mechanism that brings state and private stakeholders together in policymaking. Through a case study in the Jambi Province, we find that the collaboration between local governments and society has been effective to solve the crisis because they may share understanding to prioritise the Covid-19 pandemic as a common problem. At the same time, the religious tension also had a positive impact on the collaboration. However, the collaboration performance has followed several challenges such as incompatible procedures, inequality for the same access between individuals, and intervention by local elites.
\end{abstract}

Keywords: Collaborative Governance; Crisis; Covid-19; Local Governments; Jambi.

\section{Introduction}

Enthusiasm among experts regarding collaborative governance models has been increasing recently. The need for cooperation between government, a private and public actor is considered the best way to overcome contemporary problems such as the crisis caused by Covid-19. This is not an exaggeration considering that the Covid-19 pandemic has led to a multi-dimensional crisis that has triggered significant changes. It is just that the awareness to collaborate in dealing with the Covid-19 outbreak has not been fully present at the level of daily practice.

In Indonesia, the policy for handling Covid-19 appears to be more dominated by the government. The government issued a series of procedures such as Presidential Decree (Keppres) Number 7 of 2020 concerning the establishment of the Task Force for the Acceleration of Handling the Corona Virus and the determination of Covid-19 as a non-natural national disaster (Putsanra, 2020). President Joko Widodo also issued a policy of implementing Large-Scale Social Restrictions to prevent the broader spread of Covid-19 (Ihsanuddin, 2020). Although various procedures for handling Covid-19 have been made by the government, 
the results are still not optimal. This is at least marked by the high number of Covid-19 cases, where there are 869,600 with a death rate of 25,246 people until January 14, 2021 (Satuan Tugas Penanganan Covid-19, 2020). The high number of Covid-19 cases indicates that the government's crisis management has not been optimal. The government's response in handling Covid-19 is considered very slow, starting from the weak detection of people who bring the virus into Indonesia, the lack of availability of Personal Protective Equipment (PPE), transparency and accuracy of inaccurate data and coordination between problematic government actors.

The central government itself has not walked alone in handling Covid-19. President Joko Widodo has ordered every local government (province/ district) to participate in helping to overcome Covid-19 in their regions, such as by refocusing and reallocating the Regional Budget (APBD) forming regional task forces and increasing social assistance. However, even though the local government has carried out these various levels, it should be realised that each local government has a different APBD capacity in handling Covid-19. This can be seen in table 1 .

Table 1. Comparison of the Budget for Handling Covid-19 between Regional Governments in 2020

\begin{tabular}{|l|l|r|}
\hline No & \multicolumn{1}{|c|}{ Province } & \multicolumn{1}{c|}{ Budget } \\
\hline 1 & Prov. DKI Jakarta & 10.640 .901 .596 .980 \\
\hline 2 & Prov. Jawa Barat & 8.013 .708 .790 .648 \\
\hline 3 & Prov. Jawa Timur & 2.391 .097 .521 .006 \\
\hline 4 & Prov. Jawa Tengah & 2.126 .915 .747 .000 \\
\hline 5 & Prov. Aceh & 1.792 .367 .796 .000 \\
\hline 6 & Prov. Jambi & 49.276 .705 .321 \\
\hline 7 & Prov. Sulawesi Barat & 36.655 .766 .744 \\
\hline 8 & Prov. Bengkulu & 30.800 .000 .000 \\
\hline 9 & Prov. Nusa Tenggara Barat & 23.045 .474 .320 \\
\hline 10 & Prov. Maluku Utara & 10.246 .072 .328 \\
\hline
\end{tabular}

Resource: Ministry of Home Affairs, 2020

Based on table 1, it can be seen that there are disparities between regions in allocating budgets for handling Covid-19, where several provinces can budget a significant amount. Several regional governments such as DKI Jakarta Province, West Java Province, East Java Province, Central Java Province, and Aceh Province are the five largest regions in allocating a budget to handle Covid-19 of more than Rp. 1 Trillion. It's just that some local governments still give a minimal budget for managing Covid-19 activities. It is noted that Jambi Province, West Sulawesi Province, Bengkulu Province, West Nusa Tenggara Province, and North Maluku Province are the five lowest regional governments in allocating the budget for handling Covid-19 nationally.

In the Jambi Province, the policy for handling Covid-19 is more focused on refocusing and reallocating the Regional Budget for Covid-19 response activities. From the Ministry of Home Affairs data, the Jambi Provincial Government has budgeted for Covid-19 prevention activities of Rp. 49.2 billion. In percentage terms, this amount is only $1.07 \%$ of the total 2020 APBD of Rp. 4.56 Trillion. It should be noted that the small APBD is not a reason to allocate a small budget for handling Covid-19. Some local governments, such 
as Maluku Province, can provide up to IDR 100 billion or 5.5\% of the total APBD of 1.8 trillion. Bangka Belitung province of Rp. 25 billion or $1.08 \%$ of the total APBD of 2.3 trillion. This fact shows the commitment of the local government to determine the speed in overcoming the Covid-19 outbreak. What happened in Jambi Province is very risky, considering that until January 14, 2021, 3,807 people tested positive for Covid-19, and the death rate was 64 people (Pemerintah Provinsi Jambi, 2021). Therefore, the participation of actors outside the government in filling the limitations of local government is urgently needed. This is very common because the potential of the private sector and the community is enormous in supporting the handling of Covid-19.

Moreover, the involvement of the community in various crucial situations has proven successful in accelerating crisis management in multiple cases that have occurred in Indonesia (Stokke, Törnquist, \& Sindre, 2017; Sani \& Syamsuddin, 2020). For example, the participation of civil society is able to become a strong foundation for the creation of democracy, peace, and reduction of poverty due to the tsunami disaster in Aceh (Stokke et al., 2017). Meanwhile, the study conducted by Sani and Syamsuddin (2020) succeeded in seeing the positive role of Muhammadiyah, who was present in assisting disaster victims in the Sinjai Regency through the existence of the Muhammadiyah Regional Leadership Disaster Management Institute/Lembaga Penanggulangan Bencana Pimpinan Daerah Muhammadiyah (LPB PDM). Thus, the participation of civil society in crisis management is not a new thing to do because their involvement is real and can have positive implications for a policy.

In the discipline of public administration, the involvement of non-government actors in policymaking is often seen through the concept of collaborative governance. The main idea of collaborative governance is to unite policymakers in a collective forum to engage in consensus-oriented decision-making (Chris Ansell $\&$ Gash, 2008). A consensus-based policy orientation can only be obtained through a process of dialogue and collaboration between stakeholders (Voogd \& Woltjer, 2007). Furthermore, collaborative governance itself emphasises that the government's position is not a determinant but instead plays a role in creating conducive socio-political conditions, the private sector functions in creating jobs. In contrast, the community plays a role in mobilising individuals to solve problems (Syamsurizaldi, Putri, \& Antoni, 2019). In other words, this concept emphasises the existence of equality between the government, private sector and civil society. Moreover, equality between stakeholders can exist formally where every decision departs from sharing activities, shared structures, and shared resources (Walter \& Petr, 2000). So, it is not surprising that collaborative governance can be developed from an institutional side ( Kurniasih, 2017).

In various studies, the concept of collaborative governance has been raised on specific research themes. For example, the study conducted (Koeswara et al., 2020) outlines the policy of providing certification for the Home Food Industry (Industri Rumah Tangga Pangan/IRTP) of ground coffee in Nagari Koto Tuo, Sungai Tarab District, Tanah Datar Regency. However, it does not fully reflect collaborative governance because it is still partially carried out by each actor. Another study describes the success of community-based forest governance as strongly influenced by how successful collaborative governance is carried out (P.P, R, S, \& M, 2018). Meanwhile, Irawan Denny (2017) observes that collaborative governance is insufficient in controlling air pollution but must also be supported by other factors, namely good 
governance. Another study with issues that are different from collaborative governance was also carried out by Febrian (2016), which explains that collaborative governance-based rural development is proven to maximise the potential involvement of various parties in developing rural areas.

In the health crisis sector, some literature is also focused on collaborative governance as an essential concept to resolve the Covid-19 pandemic. Christopher Ansell, Sørensen, and Torfing (2020) argue that collaborative governance has allowed citizens and other stakeholders to participate in eradicating the Covid19 crisis, which is called robust governance. Strong governance is seen as a catalyst for achieving collaborative networks in handle crises through public engagements. Another study by Huang (2020) argues that the collaboration among stakeholders has succeeded to eliminate the Covid-19 pandemic in Taiwan. Both studies show that collaboration is an alternative concept in solving a crisis and an adaptive concept at the practical level.

Although the development of the collaborative governance concept continues to increase, there are various limitations. First, collaborative governance fails to position civil society naturally or as an organisational culture in policymaking (Brandsen, Trommel, \& Verschuere, 2017). This cannot be separated from the lack of efforts to understand more deeply the characteristics of society. Second, stakeholder understanding of this concept is often followed by an imbalance of power where the government often monopolises decision making (Warner, 2006). Third, the majority of studies on collaborative governance are conducted in standard cases. Even though in a critical situation such as the Covid-19 pandemic, the use of this concept can be attractive on how collaboration influences the handle a crisis. This study aims to explore the partnership between stakeholders in managing the Covid-19 crisis in Jambi Province. By understanding the collaboration, the future crisis can be maximally anticipated through applicable policies.

\section{Literature Review}

The concept of collaborative governance is a variant of developing the idea of governance. Governance can be defined as mechanisms, practices, and procedures for governance and citizens to manage resources and solve public problems (Klijn \& Koppenjan, 2015). In contrast to the concept of government, which refers to activities supported by formal authorities, the concept of governance, refers to actions to determine common goals. Furthermore, governance is a more comprehensive phenomenon because it embraces not only government organisations but also informal mechanisms. Therefore, there is no gap between government and non-government actors in policy formulation and implementation.

The shift from government to governance implies less government but more government or is termed (Martinez, 2011) as "hollowing out the state" or "perforating the state". Thus, the government is no longer the sole factor that determines government running, but the government collaborates with the private sector and society. This then becomes the rationale for collaborative governance, which provides space for the involvement or participation of other actors outside the government to help the limited capabilities of the government in terms of resources and finance.

In the existing theoretical discussion, collaborative governance has very diverse models. For example, Ansell and Gash (2008) divided collaborative governance into four main variables: initial conditions, 
institutional design, leadership, and collaborative processes. The initial conditions govern the basic levels of trust, conflict, and social capital that act as resources during collaboration. The institutional design contains the basic rules by which collaboration is carried out. Leadership focuses on the aspects of mediation and facilitation of collaboration. Finally, the collaborative process is at the core of the model, which contains shared understanding, outcomes, dialogue, building trust, and commitment to the process. Like what Ansell and Gash stated, Daley (2009) also describes four variables in collaborative governance: understanding of problems, experience in collaborating, leadership, and standard operating procedures. Meanwhile, Emerson and Nabatchi (2015) divide collaborative governance into three variables, namely; (1) a system context containing power relations, policies, and legal frameworks as well as experiences of conflict and cooperation,

(2) a collaborative process to produce the principle of involvement with motivation and togetherness, and (3) change and adaptation to the system context.

If you look at some of the previous collaborative governance models, three elements always appear in collaborative governance - first, the rules. The existence of rules in a collaborative policy is mandatory. It must be obeyed by all parties, considering that these rules contain objectives, principles and values that serve as guidelines in decision-making. Regulations also have a meaning as a guide in the actions of public institutions that aim to achieve specific results (Mu, de Jong, \& Koppenjan, 2019). If the rules provide discretionary space, cooperation and integration are possible in a policy. However, if the rules are rigid, the collaboration will lead to counterproductive things. The second, the collaborative process. The collaborative process can be interpreted as all the dynamics that occur in collaboration, including motivation and trust between the parties involved. Third, the meaning of the importance of the issue. The purpose of the issue will determine the degree of success of the collaboration. The more central and massive an issue is discussed in the community, the easier it is for collaboration to materialise. In addition, Avellaneda (2013) describes the meaning of the issue and can also tell it is more deeply related to political control and intervention by stakeholders.

\section{Methodology}

This article uses a qualitative research method with a case study approach considering that the problem is particular, which focuses on the Covid-19 pandemic situation. According to Creswell (2007), "a qualitative case study can be composed to illustrate a unique case, a case that has an unusual interest in and of itself and needs to be described and detailed." Therefore, using the case study approach is expected to be able to obtain relevant data and information and at the same time bring researchers to understand social dynamics as a whole through observing behaviour, actions and goals with a more natural method about a collaboration among actors in handle Covid-19 pandemic in Jambi province.

The unit of analysis in this study is a group, considering that the policy for handling Covid-19 involves multiple actors. The group classification in this study consists of local government actors, especially the specialised agencies that directly handle Covid-19. In addition, civil society actors were represented by several community organisations, civic communities, influencers, and local media. As for the private sector, 
several companies were represented that gave corporate social responsibility (CSR) in helping to handle Covid-19.

To collect data, this study uses several techniques, namely in-depth interviews, observation, and documentation. In-depth interviews were conducted using the purposive sampling technique or deliberately selecting the informants to be interviewed. The selection of informants is based on the consideration of individuals who have in-depth knowledge or are also strategically involved in handling Covid-19. In addition, the in-depth interview was analysed to understand the motives that the stakeholders to engage in collaborative governance, as for those who became informants in this study, among them came from elements of the Hospital, Health Service, Social Workforce Service, Regional Disaster Management Agency, community organisations, local media, and several private companies domiciled in Jambi City. The observations are focused on social activities carried out by several parties related to the handling of the Covid-19 pandemic. Another technique used is documentation, where the author collects research-related data in the form of budget documents, regulations and other relevant data that strengthen the findings.

\section{Result and Discussion}

The Covid-19 pandemic does not necessarily have negative implications but has contributed to a strong initiative from the public to work hand in hand with the government in overcoming the crisis. The threat of increasing death tolls and massive damage such as increasing poverty has generated strong solidarity in finding solutions. This can be seen from the government's various collaborations together with the private sector and the community during the pandemic period both spontaneously and regularly. This collaboration is possible considering that civil society is no longer the object of state policy. When examined more deeply, the degree of successful collaboration in the policy of handling Covid-19 in Jambi Province can be analysed through three variables, namely rules, collaborative processes, and the meaning of the importance of the Covid-19 problem.

For Jambi Province itself, the handling policy has referred to various regulations given by the central government, including Peru No.1 of 2020 concerning Financial Policy and Financial System Stability for Handling the Covid-19 Pandemic and Presidential Instruction Number 6 of 2020 concerning Increasing Discipline and Enforcement of Health Protocol Law in the Prevention and Control of Corona Virus Disease 2019. In the Peru Number 1 of 2020, there are at least three strategic policies, namely; (1) health in the form of activation of referral hospitals, emergency hospitals, equipment and medical support, testing and tracing physical distancing, and large-scale social restrictions, (2) social safety nets in the form of enhancement and expansion of the Family Hope Program (PKH), increase and expansion of foodstuff cards, exemption of electricity bills, and additional interest difference subsidy assistance, (3) support from the business world in the form of incentives and relaxation in the field of taxation, the national economic recovery program through State Capital Participation (PMN), and various policies and relaxation in the financial sector and involving Bank Indonesia, the Financial Services Authority, the Deposit Insurance Corporation, and the government. The Presidential Instruction Number 6 of 2020 mandates every local government to regulate and oversee 
public compliance with the implementation of the Covid-19 health protocol. Interestingly, the local government has also made various regulations, including Governor Regulation (Pergub) Number 35 of 2020 concerning guidelines for adapting new habits (new normal) to a productive and safe society for Covid-19 in Jambi Province. These rules serve to provide signposts for many parties in the success of the Covid-19 handling policy.

It's just that at the level of implementation, various regulations that have been made by the government have not been able to be implemented optimally. For example, in the context of implementing a social safety net as mandated by Peru No.1 of 2020, local governments have failed to carry out this policy maximally. This can be seen from the low realisation of the distribution of social assistance, as seen in table 2.

Table 2. Report on the Realisation of Social Assistance Distribution for JPS Jambi Province September 2020

\begin{tabular}{|c|c|c|c|c|c|c|c|c|c|c|}
\hline 5 & LAPC & $\mathbf{N} \mathbf{K} \mathbf{t}$ & TAHAP & II PER 14 S & PTEMB & ER 20 & KUVIN & AMBI & & 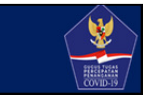 \\
\hline & & & M (KK) & NOMINAL & & REALIS & & & SALD & \\
\hline$N 0$ & 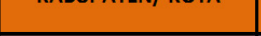 & KUOTA & REAL DATA & NTUAN & KPM (KK) & $\%$ & NOMINAL & KPM (KK) & $\%$ & NOMINAL \\
\hline 1 & BATANGHARI & 3.371 & 3.371 & 2.022 .600 .000 & 3.371 & 100,00 & 2.022 .600 .000 & 0 & 0,00 & 0 \\
\hline 2 & BUNGO & 2.036 & 2.036 & 1.221 .600 .000 & 1.443 & 70,87 & 865.800 .000 & 593 & 29,13 & 355.800 .000 \\
\hline 3 & KERINCI & 2.438 & 2.438 & 1.462 .800 .000 & 60 & 2,46 & 36.000 .000 & 2.378 & 97,54 & 1.426 .800 .000 \\
\hline 4 & KOTA JAMBI & 3.012 & 3.012 & 1.807 .200 .000 & 0 & 0,00 & 0 & 3.012 & 100,00 & 1.807 .200 .000 \\
\hline 5 & KOTA SUNGAI PENUH & 1.013 & 1.013 & 607.800 .000 & 973 & 96,05 & 583.800 .000 & 40 & 3,95 & 24.000 .000 \\
\hline 6 & MERANGIN & 3.633 & 3.633 & 2.179 .800 .000 & 935 & 25,74 & 561.000 .000 & 2.698 & 74,26 & 1.618 .800 .000 \\
\hline 7 & MUARO JAMBI & 3.632 & 3.632 & 2.179 .200 .000 & 1.872 & 51,54 & 1.123 .200 .000 & 1.760 & 48,46 & 1.056 .000 .000 \\
\hline 8 & SAROLANGUN & 3.131 & 3.131 & 1.878 .600 .000 & 0 & 0,00 & 0 & 3.131 & 100,00 & 1.878 .600 .000 \\
\hline 9 & TANJUNG JABUNG BARAT & 3.523 & 3.523 & 2.113 .800 .000 & 3.523 & 100,00 & 2.113 .800 .000 & 0 & 0,00 & 0 \\
\hline 10 & TANJUNG JABUNG TIMUR & 2.500 & 2.500 & 1.500 .000 .000 & 2.500 & 100,00 & 1.500 .000 .000 & 0 & 0,00 & 0 \\
\hline 11 & TEBO & 1.711 & 1.711 & 1.026 .600 .000 & 1.711 & 100,00 & 1.026 .600 .000 & 0 & 0,00 & 0 \\
\hline & JUMLAH & 30.000 & 30.000 & 18.000 .000 .000 & 16.388 & 54,63 & 9.832 .800 .000 & 13.612 & 45,37 & 8.167 .200 .000 \\
\hline
\end{tabular}

Source: Jambi Province Social and Manpower Office, 2020

From table 2, it can be seen that budget policies in handling Covid-19 seem to have been dealt slowly by several local governments. It can be seen that there are still some districts/cities in Jambi Province that have not yet realised social assistance for the September 2020 period, including Jambi City and Sarolangun Regency. The lack of budget absorption in several regions is admittedly because the local district/city governments are still struggling to collect data on recipients deemed worthy of receiving social assistance.

The rigidity of local government officials in accelerating the realisation of Covid-19 assistance can also be seen from the distribution of donations provided by the community. An initiative of the Jambi Provincial Government through opening a donation account for Covid-19 handling assistance since March 2020 and managed to collect assistance of IDR 760,037,137 turned out not to be able to distribute at all. Although the amount of donations received from the community is quite large, the local government has not used the assistance in these accounts. Public donation money has not been used in the Covid-19 donation account because there are no technical rules for operating funds. One informant stated:

\footnotetext{
"... don't let us, who are handling disasters today, get hit by disasters later" (Informant P, 2020).
} 
In this statement, there is much ambiguity among government officers in response to the Covid-19 pandemic. On the one hand, they are caught between a limited resource, which they ask support from the public, and, on the other hand, failing to execute a donation by the community. Moreover, we also found that most local government officers have failed to provide necessary explanations of Covid-19 donations. This demonstrated a lack of transparency in distributing information related to the list of donors with state secrets reasons. Based on our fieldwork, the local government officer never seems accountable to the public. This situation made distrust in implementing the acceleration of the policy for handling Covid-19 in Jambi Province. This confirms that even in a crisis, the local government is still trapped in running the bureaucracy in a business-as-usual way, filled with its rigid nature, stuck with routine, and procedural (Codreanu, 2016). This situation is an anomaly because, in a modern organisation, the bureaucracy has flexible authority with discretion (Kabullah, 2018). This should be anticipated in advance if the local government has a sound data system.

For civil society itself, the existence of these regulations only helps partially in handling the Covid19. Awareness of implementing 3M's new habits, namely washing hands, using masks and maintaining distance, has not been maximised. Even though the local government has carried out various socialisation activities in appeals in public rooms and carried out mask raids on several protocol roads, it's just that this step is only temporary and is carried out unilaterally by the local government. As a result, the success of implementing regulations in the policy of handling Covid-19 in Jambi Province is very dependent on the local government without any fundamental role for the community.

Another thing that can be seen in the collaborative handling of Covid-19 policies is the collaborative process. The collaborative process looks at the motivation that emerges from stakeholders in supporting policies for handling Covid-19. From the local government's point of view, the motivation present for overcoming Covid-19 is based more on the primary duties and functions inherent in the government apparatus. This is different from the motivation that comes from the public and the private sector. Massive coverage of the Covid-19 pandemic has received widespread public attention. Various civil society organisations appear to be directly involved in providing social services. Organisations such as Pemuda Pancasila are active in holding social services in several urban villages in Jambi City. Pemuda Pancasila members appear in full uniform in social service activities. They came using open vehicles carrying clean water. There is an organisational banner in the vehicle as socialisation for their concern. This reflects an ideological motive that departs from the vision and mission of Pemuda Pancasila. The same thing is also found in regional ties-based organisations, school/university alumni, and others. These various organisations seemed enthusiastic about carrying out social mobilisation actions. It's just that the activities carried out were sporadic, which was only carried out in the early days of media coverage of Covid-19, which was around March and April.

In contrast to the social organisation motive, which only lasted a short time, several other community groups mobilised support for people affected by Covid-19 spontaneously. In addition, at several points that the researchers encountered, namely, the Tugu Juang and Sipin area, help from the private sector, such as restaurant owners, provided free food assistance to survivors, as shown in Figure 1. 
Figure 1. Giving Free Packaged Rice at the front of Oey Coffee Restaurant

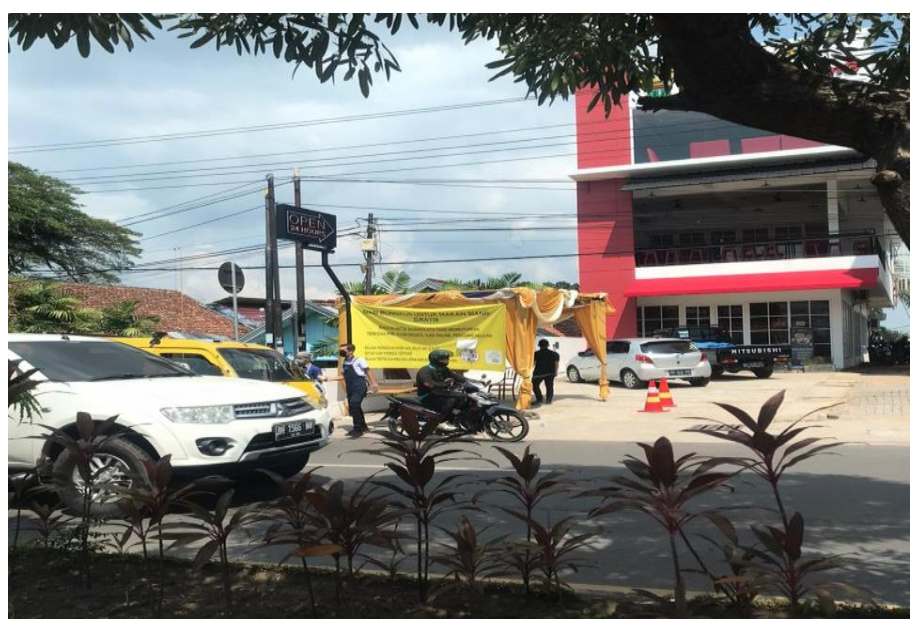

Source: Researcher's Documentation, 2020

Figure 1 shows one of the waiters at a restaurant in Jambi City who gives rice every lunch hour. The restaurant owner instructed his subordinates to provide 50 packs of rice every day on the roadside. The attitude of the restaurant owner was responded enthusiastically by road survivors, especially public transport drivers and online transport drivers. Besides restaurant owners, several community individuals are also active in assisting in other areas in Jambi City. One person who donated said that his motivation to give packaged rice was part of the act of "alms" (interview with informant A, 2020). Interestingly, this movement was carried out by informant A long before Covid-19 occurred. Thus, community support based on religious motives has hope for success in crisis management. Even so, the community's sincere motivation to succeed in handling Covid-19 is often tucked into political motivation. Elites or successful teams conduct socialisation and invitations to vote ahead of the Jambi Province Governor Election on December 5, 2020, using assistance. In some cases, the socialisation of masks and compliance with health protocols was conveyed through various public spaces such as billboards, advertorial mass media, and others. Besides that, they are also active in carrying out social programs such as providing masks, providing essential food assistance, to providing handwashing facilities in several public locations, such as figure 2.

Figure 2. Provision of a Free Hand Washing Place by a Candidate Pair for Governor at the Villa Kenali Market, Jambi City

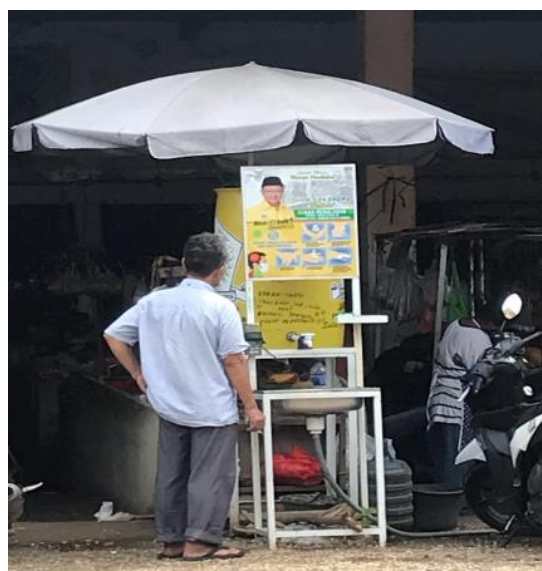

Source: Researcher's Documentation, 2020 
These various activities gave a powerful message that the Covid-19 crisis was also being responded to politically by the elite. In other words, Covid-19 was successfully used by regional head candidates as a campaign momentum. This indicates the popularity motive of the local elite that accompanies efforts to build enthusiasm from civil society in accelerating the handling of Covid-19. This pattern is typical because the presence of central figures in the civil society movement tends to be trial and error in pursuing personal motives so that they seem to replace blueprints and policy solutions (Brandsen et al., 2017).

Another factor that can be seen in collaborative governance in handling Covid-19 is the interpretation of the importance of the issue. If a problem is prioritised and campaigned en masse, the success rate of collaboration will be even greater. The Covid-19 pandemic that has occurred since February has attracted serious attention from the public. Covid-19 news delivered regularly by the government through the Covid19 National Task Force raises public sympathy to care about helping the affected communities. Especially with the entry of the fasting month of Ramadan in April, the residents' initiative to help each other is getting stronger. Social service activities are rife by the government, the private sector and the community before breaking the fast. Scholars' various invitations regarding multiple rewards for alms encourage many parties to help people affected by Covid-19.

At the same time, various calls for solidarity emerged through the media, especially electronic media and social media. There have been movements such as the Seribu Sehari Jambi II Almsgiving with 2,415 members and the Saleh Charity Force (pasta) on several social media such as Facebook. The Facebook timeline on the group's page is filled with invitations and news about social activities. Interestingly, they also often insert Al-Qur'an letters that invite everyone to give alms. Inevitably, this social media-based support was able to generate strong solidarity. This phenomenon seems to be in contrast to the situation that occurred in India, where the inaccuracy of information conveyed in religious messages raises the problem of the slow handling of Covid-19 health (Al-Zaman, 2020).

Although the enthusiasm that occurs is very high, this still shows a weakness where there is a concentration of aid received by the community. This is exacerbated by the absence of an accurate database from the local government for people who deserve to receive assistance, a situation that indicates alienation from stakeholders in implementing policies (Kabullah, Koeswara, \& Rahmadi, 2020). As a result, several small groups of people took advantage of this by begging for help on the side of a protocol road in Jambi City. In addition, the phenomenon of many poor people in the fasting month makes it very difficult for the community to verify whether the assistance provided has been given right on target. This means that sporadic aid is not necessarily effective in assisting local government policies in handling Covid-19.

Based on the above phenomena, it can be seen that the collaboration that occurs between actors is a positive thing for the handling of Covid-19. Even so, the cooperation that has been built between the government, private sector and civil society is still running simultaneously. Local governments often run counterproductive, which has implications for the dysfunction of the collaboration that is built. Even though a crisis such as the Covid-19 pandemic needs to open the eyes of local governments, many problems that cannot be reached are resolved by themselves. Willingness and trust to work together between the government, the private sector, and the community are the keys to the success of collaborative governance. 
If this happens, the collaboration will encourage the transformation of a new civil society. Expectations with the presence of a new civil society that prioritises the spirit of cooperation are enormous in accelerating policy implementation, something the government cannot do because of the rigidity of the bureaucracy. For this reason, the resolution of a public problem carried out through a global and collaborative scale is a necessity or a Ritzer dan Malone (2000) term it as 'glocalisation'.

\section{Conclusion}

The role of the state in a crisis like Covid-19 can be contradictory given the sluggish bureaucratic culture. For this reason, the presence of the private sector together with the community is part of the solution. The government must realise that its function in government administration is no longer dominant. The government cannot monopolise public affairs because society cannot be separated from matters involving their interests. For this reason, it is essential to build the participation of all parties in handling Covid-19 based on collaborative governance.

However, the importance of collaboration in crisis management has not been accepted by all parties. There is still a perception among government officials that the role of the public in a crisis is considered not to have the strong legitimacy that the government has. Moreover, the government has often considered itself as a representation of public authority so that it tends to define social relations and public responsibility from a single government point of view. At the same time, the public initiatives in helping the crisis can be exploited by a handful of parties who have their mission. For this reason, several efforts that can be made include the community must realise that the emergence of solidarity can only occur if it is based on solid motives. For this reason, the identification of motives can be a foundation in building solidarity. In addition, it is necessary to optimise community participation in the Covid-19 crisis, which can be done by involving local values.

Community involvement, which often occurs spontaneously in crises, needs to be anticipated by developing strong institutional-based community movements. For this reason, a collaboration between civil society groups is necessary. It is the responsibility of the state not only to co-opt or integrate but also to bring up civil society. For this reason, it is required to provide various spaces for public discussion as an arena for generating initiatives from the community.

\section{Reference}

Al-Zaman, M. S. (2020). Politics meet healthcare? Religious misinformation in India during the COVID-19 pandemic. Jurnal Sosial Humaniora. https://doi.org/10.12962/j24433527.v13i2.8119

Ansell, Chris, \& Gash, A. (2008). Collaborative governance in theory and practice. Journal of Public Administration Research and Theory. https://doi.org/10.1093/jopart/mum032

Ansell, Christopher, Sørensen, E., \& Torfing, J. (2020). The COVID-19 pandemic as a game-changer for public administration and leadership? The need for robust governance responses to turbulent problems. Public Management Review. https://doi.org/10.1080/14719037.2020.1820272

Avellaneda, C. N. (2013). Mayoral decision-making: Issue salience, decision context, and choice constraint? 
An experimental study with 120 Latin American mayors. Journal of Public Administration Research and Theory. https://doi.org/10.1093/jopart/mus041

Brandsen, T., Trommel, W., \& Verschuere, B. (2017). The state and the reconstruction of civil society. International Review of Administrative Sciences. https://doi.org/10.1177/0020852315592467

Creswell, J. W. (2007). Qualitative Inquiry \& Research Design. Sage Publications, Inc. https://doi.org/10.1111/1467-9299.00177

Codreanu, A. (2016). A VUCA Action Framework for a VUCA Environment. Leadership Challenges and Solutions. (2016). Journal of Defense Resources Management.

Daley, D. M. (2009). Interdisciplinary problems and agency boundaries: Exploring effective cross-agency collaboration. Journal of Public Administration Research and Theory. https://doi.org/10.1093/jopart/mun020

Denok Kurniasih, Paulus Israwan Setyoko, dan M. I. (2017). Collaborative Governance Dalam Penguatan Kelembagaan Program Sanitasi Lingkungan Berbasis Masyarakat (SLBM) Di Kabupaten Banyumas. Sosiohumaniora.

Emerson, K., \& Nabatchi, T. (2015). Collaborative governance regimes. Collaborative Governance Regimes. https://doi.org/10.1111/padm.12278

Febrian, R. A. (2016). Collaborative Governance Dalam Pembangunan Kawasan Perdesaan (Tinjauan Konsep dan Regulasi). Wedana.

Huang, I. Y. F. (2020). Fighting COVID-19 through Government Initiatives and Collaborative Governance:

The Taiwan Experience. Public Administration Review. https://doi.org/10.1111/puar.13239

Ihansuddin. (2020, March 31). Pembatasan Sosial Berskala Besar, Jokowi Tegaskan Ambil Langkah Hukum. Kompas. https://nasional.kompas.com/read/2020/03/31/16080611/pembatasan-sosial-berskala-besarjokowi-tegaskan-polri-bisa-ambil-

langkah\#utm_source=www.kompas.com\&utm_medium=kgbreakingnews

Irawan Denny. (2017). Collaborative Governance (Studi Deskriptif Proses Pemerintahan Kolaboratif Dalam Pengendalian Pencemaran Udara di Kota Surabaya ). IR-Perpustakaan Universitas Airlangga.

Kabullah, M.I. (2018). The Limits of Weberian on Anti-Corruption Approaches in the Indonesian Municipalities. In IOP Conference Series: Earth and Environmental Science (Vol. 175). https://doi.org/10.1088/1755-1315/175/1/012083

Kabullah, M. I., Koeswara, H., \& Rahmadi, D. (2020). Alienasi Kebijakan Anggaran Provinsi Riau dalam Pencegahan dan Pengendalian Kebakaran Hutan dan Lahan. Jurnal Administrasi Dan Kebijakan Publik. https://doi.org/10.25077/jakp.5.2.114-133.2020

Klijn, E. H., \& Koppenjan, J. (2015). Governance networks in the public sector. Governance Networks in the Public Sector. https://doi.org/10.4324/9781315887098

Koeswara, H., Aromatica, D., Yulivestra, M., Kabullah, M. I., Liesmana, R., \& Hidayat, E. (2020). Collaborative Governance dalam Kebijakan Sertifikasi Produksi Pangan Industri Rumah Tangga Kopi Bubuk Koto Tuo Kabupaten Tanah Datar. Jurnal Administrasi Dan Kebijakan Publik. https://doi.org/10.25077/jakp.5.2.193-207.2020 
Mu, R., de Jong, M., \& Koppenjan, J. (2019). Assessing and explaining interagency collaboration performance: a comparative case study of local governments in China. Public Management Review. https://doi.org/10.1080/14719037.2018.1508607

Pemerintah Provinsi Jambi (2021, January 14). http://corona.jambiprov.go.id/

Putsanra, D. V. (2020, March 16). Update Corona Indonesia: Covid-19 Indonesia Bencana Nasional, Kasus Capai 117. Tirto. https://tirto.id/update-corona-indonesia-covid-19-bencana-nasional-kasus-capai$117-\mathrm{eFq} 1$

P.P, E., R, R., S, R., \& M, A. (2018). Collaborative Governance Tata Kelola Hutan Berbasis Masyarakat. Lembaga Penelitian, Publikasi dan Pengabdian Masyarakat (LP3M) Universitas Muhammadiyah Yogyakarta.

Ritzer, G., \& Malone, E. L. (2000). Globalisation Theory: Lessons from the Exportation of McDonaldization and the New Means of Consumption. American Studies, 41(2/3), 97-118. https://doi.org/10.2307/40643232

Sani, K. R., \& Syamsuddin, S. (2020). Peran Lembaga Muhammadiyah dalam Mitigasi Bencana di Kabupaten Sinjai. Jurnal Sosial Humaniora. https://doi.org/10.12962/j24433527.v13i1.6648

Satuan Tugas Penanganan Covid-19. (2021, January 14). https://covid19.go.id/peta-sebaran

Stokke, K., Törnquist, O., \& Sindre, G. M. (2017). Conflict Resolution and Democratisation in the Aftermath of the 2004 Tsunami: A Comparative Study of Aceh and Sri Lanka. PCD Journal. https://doi.org/10.22146/pcd.25670

Syamsurizaldi, S., Putri, A. A., \& Antoni, S. (2019). Model Collaborative Governance pada Nagari Rancak di Provinsi Sumatera Barat. Jurnal Pembangunan Nagari. https://doi.org/10.30559/jpn.v4i1.88

Walter, U. M., \& Petr, C. G. (2000). A template for family-centered interagency collaboration. Families in Society. https://doi.org/10.1606/1044-3894.1051

Warner, J. F. (2006). More sustainable participation? Multi-Stakeholder Platforms for integrated catchment management. International Journal of Water Resources Development. https://doi.org/10.1080/07900620500404992 